\title{
REORGANIZATION FOR POLICE PROTECTION
}

\author{
DONAID C. STONE*
}

Recent federal legislation in the field of crime and law enforcement has focussed nationwide attention on the effectiveness of our existing police machinery. The first group of these bills passed by the Seventy-third Congress seeks to strengthen federal law enforcement in matters with which the federal government is already concerned; a separate group extends federal police jurisdiction to crimes which heretofore have been entirely state and local problems; the purpose of a third group was to increase the effectiveness of existing federal police agencies, particularly the Division of Investigation of the United States Department of Justice.

Passage of these bills raises such questions as what is the logical responsibility of federal, state, and local police agencies; what organizational and personnel problems stand in the way of further efficient development of police service; and the extent to which police control should be centralized in state and federal governments.

\section{Shifts in the Police Problem}

Problems which this recent federal legislation seeks to solve are relatively of recent origin. At least the task of crime suppression has undergone striking change in the past few years. The advent of the automobile has probably done more than anything else to alter the operations of criminals and of police methods. People are no longer tied to a radius of a few miles of their home, but they are dashing about under their own automotive power covering hundreds of miles during a single day in search of pleasure and business. The patrol officer no longer can keep track of the whereabouts of residents on his beat; strange faces have multiplied through the expanding circulation of people so that the officer can hardly distinguish between a local resident and a visiting desperado. A hold-up gang in a few hours can be beyond an adjoining state far beyond the grasp of officers where the crime is committed. The automobile has made crime an inter-city and interstate problem. Local agencies can not cope with it unaided.

A second development transforming the nation's police problems and shaking the very stability of our civilization is the development of rackets of every kind and

- A.B., Colgate; B.S. in Public Administration, Syracuse. Director, Consulting and Rescarch Division of Public Administration since 1933. Staff of Cincinnati Bureau of Governmental Research, 1926-1927; Committee on Crime Records of the International Association of Chiefs of Police, I928-I929; Director of Research, International City Managers' Association, r929-1933. 
description. With the centralization of business enterprise, with the dawn of big finance, and with the tremendously increased variety of business and social activities, rapacious manipulation and self-seeking avarice more easily victimize the rank and file of the citizens. Organizations of endless number have been developed to advance personal interest and financial gain through grasping methods many of which are at least unethical if not unlawful. The variety of rackets is endless; they thrive in small towns as well as large, wherever men try to get something for nothing or through greed strive to better their position so that their friends or relatives may be placed in better position with resulting financial gain. Politicians, judges, labor unions, lawyers, bail bond brokers, bankers, newspapers, social organizations, magazine subscription sellers, as well as medicine fakirs, fortune tellers, and gambling operatives have often prostituted a gullible public to selfish aims as Dean Justin Miller so ably pointed out last year at the annual convention of the International Association of Chiefs of Police. He illustrated the difficulty if not impossibility of drawing the line between legitimate practice and genuine rackets.

Rackets are not new. They have existed since primitive man preyed on his weaker members. The only difference between today and yesterday is that the complexities of life have increased their complexity, variety, and number.

Profound changes are also being wrought in family life, in social attitudes and in public character. The disintegrating forces of the depression and the destitution it has brought with it, the wavering uncertainties in liquor control, the introduction of both young and old to a daily round of impressions from movies and the radio are altering customs and beliefs. Studies encouraged by the Payne Fund reveal that radio and movies may be breeding anti-social and destructive tendencies more effectively than we suspect. It is these changes providing background for bold, dramatic kidnapings, murders, hold-ups, extortions, blackmailings, embezzlements, and forgeries, which have set the scenes for the recent federal legislation.

Reflecting these changes in community life, cities, counties, states, and the federal government have adopted regulatory ordinances and statutes covering a multitude of subjects which restrict and control the citizen at every turn. Traffic, sanitation, health, building, and similar codes require enforcement, the burden of which falls largely upon the police. Liquor stores, pool rooms, dance halls, all require regulation. The chief work of the police is no longer catching thieves, solving murder mysteries, and searching for stolen property, but rather the enforcement of minor regulations which enmesh the every day life of citizens, whether rich or poor, urban or rural.

It is these changes which must be kept in mind in any basic reorganization plan for police protection.

\section{The Importance of Personnel}

The effect upon police work which these great changes have wrought is illustrated by a job analysis prepared by the Los Angeles Police Department under the leader- 
ship of the California State Department of Education. This analysis reveals that 104 different kinds of duties of the patrol service require 158 kinds of knowledge to perform these duties. Listed among these special kinds of knowledge are "how to recognize evidence of domestic difficulties or improper conduct of juveniles"; "how to adjust or advise proper remedy in cases of neighborhood quarrels and domestic difficulties, relations of master and servant, buyer and seller, lender and borrower, miscellaneous unethical practices"; "habits and tendencies of people on the police beat"; "ways and means of crime prevention"; "habits, methods and jargon of felons"; "how to select locations on the beat in which crime is likely to be committed"; "methods and procedure in missing persons, psychopathic, attempted suicides, and military deserter cases." Then in addition of course there are the almost endless variety of specialized police techniques such as methods of investigation of different crimes, knowledge of criminal modus operandi, criminal procedure, criminal identification, rules of evidence, handling mobs, criminals, traffic control, ballastics, chemistry, radio, and many others.

These required knowledges illustrate the gradual change from that of crime suppression to crime prevention.

Today men of quite different aptitudes and abilities are required than when the police departments of a decade ago were faced with relatively simple problems. Police chiefs are recognizing that particular adaptability, character, and training are required; they are realizing that effective police administration is chiefly a question of securing competent man power with permanent term of office free from political influence. Studies of police agencies demonstrate that those departments and those alone which meet this test are proving successful. With capable, trained men under effective leadership, all other problems except political interference can be readily solved.

The Division of Investigation of the United States Department of Justice illustrates a most efficient organization resulting chiefly from the fact that its men are selected because of their special qualifications for the work, and are given splendid training and leadership once in the service. Free from political manipulation, the Division has supplied an extraordinarily high degree of resourceful management which has built up the technical knowledge, the interest, and the professional attitude of the men to the point where they represent an outstanding example of police efficiency.

State police forces further exemplify the successful results that can be secured by observance of these fundamental requirements. Several of their forces are splendid organizations, providing efficient service, free from politics.

Municipal police forces illustrate vividly the good results from recognizing these essential requirements and the bad results from not recognizing them. Some city police departments are fortunate in securing able leadership with permanency in tenure of office with the result that competent men have been recruited and trained 
to furnish reliable, effective police protection. In too many departments, however, police executives are forced to continue with a large portion of the force composed of old men, too old to learn the new techniques of modern police service. The police force is the chief plum of any self-seeking politician who, unless kept at arms length, will subject it to subversive interests destroying its serviceableness. Not until we look upon government in general and police service in particular as a technical, professional undertaking can we expect to develop competent police departments in every area as has been done in some progressive communities which have insisted that political bosses shall be kept off and out of city hall.

\section{Handicaps in Police Structure}

Faced with complex crime problems and terroristic operations of criminals, one would think if we were reasonable people that we would establish a system of police protection organized on a scale commensurate to the problems encountered. But what do we find? We find small police forces, too small to play any significant part in crime repression; we find badly organized police agencies; we find overlapping and conflicting police agencies. We fail to find uniformity in recruitment, training, or standard of performance. In brief, a maze of about fifty thousand police agencies, all unrelated to each other without any unity of command, peck away, often too feebly to be felt, at the monster called crime.

Let us examine state government more closely. The constitution of a state generally places responsibility for the executive of state laws on the shoulders of the governor, but the governors under these same constitutions are given no authority or facilities to enforce these responsibilities. The relatively recent establishment of twelve state police agencies and more than twice this number of state highway patrols has been the first real attempt in a small way to permit the governor to carry out his sworn obligation. Since the state police are generally restricted in their jurisdiction to unincorporated territory of the states, the extent of the governor's authority is not very much enlarged.

In very few of the states do the governors have any jurisdiction over the attorney general, the prosecuting officer of the state. The attorney general usually is elected and runs his own show. But his show is not very large since he has little if any authority over prosecutions in the cities and counties which constitute all but a small part of criminal proceedings within a state.

Turning from the state to local law enforcement, we find the county sheriff upon whom nearly half of the population of the United States relies for protection to life and property and for the preservance of peace. If a deliberate attempt were made to establish an inefficient and inadequate system of police protection, it is difficult to imagine how a plan could be devised with more certainty of failure than what we have permitted to grow up in the form of the county sheriff. The sheriff is an elected officer and, therefore, he is a politician. He occupies a short term and in many states cannot succeed himself; if he can, much of his time must necessarily 
be spent in building up political fences for the next election. His area of jurisdiction is so small that it will not permit of a sufficient number of deputies to enable the specialization that is required in modern police administration. Usually such deputies as are appointed are political and with few exceptions, every time the sheriff goes out of office, his deputies go with him. Perhaps the political nature of the position of sheriff is the explanation why this office persists so tenaciously.

Only when we turn to cities do we find local police forces established on a basis which permits possibility of success. But we have handicapped the city forces. In the first place a single police force does not ordinarily have jurisdiction over all urban area in any metropolitan region. The majority of cities are hedged by suburban residential areas, towns, and satellite communities which maintain separate police agencies all independent of one another. Coördination and effective police programs throughout this area which provides a single police problem are obviously impossible.

\section{Area of Jurisdiction An Obstacle}

In the second place most of these municipal police forces do not have jurisdiction over an area of sufficient size with sufficient population to warrant a large enough force to perrnit the specialization of staff services such as records, communications, identification, training, and expert investigational facilities which are essential in the present day solution of crime. A one-man, a ten-man, or perhaps a fifty-man police force is too small to support the kind of police program which is indispensable in equiping policemen to cope with the complex character of crime and law enforcement. I do not know what is the minimum size for an efficient police department, but I suspect it is not less than a hundred men; which would mean that cities with a population less than fifty or perhaps sixty thousand are fundamentally too small to maintain all service required in effective policing. This is a subject worthy of real study.

In contrast we see England and Wales countenancing 182 police establishments in the entire country, whereas in the United States there are thousands of police units ranging from our metropolitan forces to village police, isolated constables, and marshals. In England each of the large cities maintains its own police organization. The policing in cities not maintaining forces, and some of these have as many as one hundred thousand inhabitants, as well as the policing of all rural areas, is performed by country constabularies. This small number of police units in England is not accidental but is the result of a deliberate attempt to eliminate small, ineffective units. Even some of the existing units are considered too small and are being consolidated.

The lack of correlation between the various branches of law enforcement also blocks the way to efficient crime protection. Regardless of the efficiency of the police, if the prosecution is ineffective or the courts political, no community can expect to suppress crime. Police and prosecution agencies are completely independent of each other in the United States, and in the case of municipalities prosecution of indictable 
crime is not attached to the same unit of government as the police. Many a good police force has been demoralized by politically controlled prosecutors and courts who let criminals go unpunished. We cannot expect a united front until police and prosecution become coördinated and responsible agencies under the same unit of government, either by incorporating the prosecution as a part of the police department, or placing both the police and prosecution under the same chief executive. This is what we have done with respect to federal crimes where both the chief investigational agency and the prosecution agency are divisions within the United States Department of Justice.

\section{Who Shall Control the Police?}

What would constitute a rational program for police organization based upon our present philosophy of local self government? First of all, we should continue to improve and consolidate federal police agencies. Their jurisdiction should be extended with caution and should embrace only crimes of an interstate character. Within a state all large cities should be organized into a single unified police department. The jurisdiction of sheriffs and other duplicating and overlapping police agencies should be abolished. Outside of the urban centers reliance should be placed upon a state police force with the position of sheriff, marshal, constable and coroner abolished. This may sound drastic, but it is drastic only because of the obstacles encountered in the form of state constitutions, political power of entrenched interests, and the apparent apathy of the public to take the government in its hands and make of it a useful instrument of service. If this type of program is carried out there will be little need for expanding the jurisdiction of federal police agencies. If it is not carried out state and local government will be further shorn necessarily of present responsibilities. Thus the American public faces the choice either of an increase in centralization of police power in the federal government on the one hand or the establishment of well-organized city and state police on the other.

Perhaps a system of federal grants-in-aid may be developed as often proposed. Such a system will not necessarily mean centralization of administrative control over state and local forces. It would result in the imposition of some kind of standard relating to number of men on the forces, recruitment and training requirements, and equipment. The net effect of subventions is always to place great influence in the hands of the giver. This influence can be very beneficial as it has been in the case of grants by the federal government for roads, education, and relief, to mention only a few fields in which we have had experience. England furnishes an example of a most successful system of grants-in-aid, but under conditions much more agreeable to the success of this principle.

Suggestions have been made from time to time that state governments establish the grant-in-aid plan or at least a bureau with authority to impose standards on local forces. An inspection of state governments reveals that they are far more political in their organization and operation than city government, so that such control 
might result in placing efficiently managed cities of which there are hundreds in an embarrassing position. Many cities in states are more important fiscally than the states that contain them, and all are of greater significance in terms of services rendered. The state is purely an artificial unit, which may have outlasted a considerable part of its usefulness. Thus if cities are exempt from state control, rural government alone remains and this can be policed best by a single state police force. Granting that this kind of set-up will not be effected at an early date, an advisory service to local police might be established as a part of the state government, placed perhaps in the state department of justice proposed recently at the Milwaukee meeting of the American Bar Association. Guard must be made against placing such an agency in hands independent of the governor, as would result by placing it under the attorney general of most states. We need more responsiveness and unity in state government, not less. The state bureaus of criminal identification, investigation, and statistics described below can be effective forces in improving local policing. But they have to be managed more adequately than many of those already existing, which are starved for funds. If many states have not been able to demonstrate that they can administer existing identification bureaus effectively, how can we expect them to shoulder successfully a similar but more difficult problem? The problem is not so much one of legal machinery as it is of administrative capacity. Intelligence is the chief requirement, not teeth.

\section{The Sphere of Coöperation}

Increasing the effectiveness of police agencies fortunately does not depend alone upon the bringing about of a reorganization of existing forces. Departments are adopting many coördinating and coöperative undertakings to the misfortune of the offender. The national division of identification in the Department of Justice, an indispensable aid in crime detection and apprehension, is purely a coöperative undertaking. Police forces submit voluntarily finger prints, crime reports, and other information. Indeed this identification division was initiated, conducted, and paid for by voluntary assessments on local departments by the International Association of Chiefs of Police before transference to the Department of Justice.

Although local police agencies are required by law to submit identification data, state bureaus of identification are essentially coördinating agencies. They do not interfere with local police authority. Here again the International Association of Chiefs of Police through the assistance of Public Administration Service and of Professor Ernst W. Puttkammer of the University of Chicago Law School has prepared a model state bill of criminal identification, investigation, and statistics. The purposes of this bill are the establishment of a clearing house for identification data, lost and stolen property reports, and crime statistics for all law enforcement agencies within the state. The bill provides for a staff of specialist investigators who may be called in voluntarily by local police officers to assist in investigating unusual crimes or to aid in emergencies at the order of the governor. Statewide communications 
such as radio, telegraph typewriter hook-ups, and scientific laboratory facilities, are part of the proposed set-up.

Police officers within a region are finding it profitable to join together in coöperative enterprises. In the San Francisco region we find peace officers meeting monthly to discuss law enforcement problems and means of mutual assistance. Cincinnati, following an intensive study by Bruce Smith of the Institute of Public Administration, has developed an elaborate program of police coöperation. The heads of 78 police units covering six counties in three states have established a formal organization called the Cincinnati Regional Police Association, which meets bimonthly. This Association has developed a unified radio broadcasting system for the region, central police training facilities, a central record and identification bureau, programs of mobilization in case of emergency, and a system of control points under which all main roads in the area can be covered upon short notice. Similar organizations exist in other metropolitan regions.

\section{The International Association of Chiefs of Police}

The International Association of Chiefs of Police and the newly organized State Police Executives of the United States are important forces bringing about coördination in police activities. The I. A. C. P. in addition to establishing the national division of identification and the nationwide system of uniform crime reporting now operated by the United States Department of Justice has for many years been engaged in a wide program of improvement of police administration. The development and spread of police radio has been greatly stimulated by the work of the Association. The Association for many years has encouraged the establishment of police training schools. Not only do we find such schools in practically all major cities in the country, but during the last few years we have witnessed the establishment of state-wide police training schools conducted jointly by state leagues of municipalities and state police chiefs associations. The zone school system in New York state and in Virginia are noteworthy as pioneer examples.

In order to raise standards of police personnel the International Association of Chiefs of Police two years ago requested the United States Civil Service Commission to prepare a standard police adaptability test. Through the assistance of Public Administration Service this test has been furnished to over a hundred police departments who have examined the members of their forces. Not only is this enabling minimum standards of recruitment to be established, but equally significant is the fact that police executives in these cities are analyzing their men, weeding out the inefficient, promoting the most competent, and initiating an intelligent program of personnel management. During the current year the Association started the publication of a monthly Police Chiefs News Letter in order to keep its members informed of developments and improvements taking place in the police field. 


\section{Coördinating Community Agencies}

But the coördination of police agencies is not enough. Many other agencies in a community have law enforcement responsibility. As a means of coördinating these diverse agencies, cities are turning to the establishment of what are known as coördinating councils. They are formal organizations consisting of the executive heads of the police, prosecution, courts, probation, schools, welfare, and recreation departments of correctional institutions, juvenile agencies, mental hygiene clinics, and various private social character-building organizations.

Some of these councils employ full time administrative staffs. Councils in Los Angeles, San Francisco, Oakland, Berkeley, and Santa Maria, California, are illustrations of the successful organization of city and rural units of different sizes.

The coördinating council is a planning and deliberating body holding meetings monthly or more frequently at which the members discuss specific problems concerning maladjusted individuals and problems of law enforcement. The major purpose is the formulation of a balanced, coordinated social welfare program for the community. They work out methods for eliminating duplication of effort which is so prevalent in many communities. I recall very vividly the meeting of one of these councils at which was discussed the recent murder by a boy of twenty who had been handled or treated by eight or nine of the community organizations represented on the council. This council sought an answer to the question: "where have they failed in the treatment of this murderer in the earlier stages of his career?" With such kind of responsibility assumed by coördinating councils, there is great hope that through voluntary changes effective and successful programs will reduce and stamp out the evil called crime. 